\title{
噴霧熱分解法によるリチウムー次電池用二酸化マンガンの合成
}

\author{
宮本 信明*，釷野 智史，中本 貴大
}

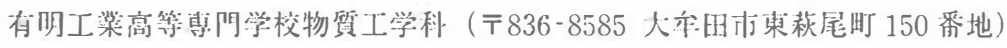

\section{Synthesis of Manganese Dioxide by Spray Pyrolysis for Lithium Primary Cell}

\author{
Nobuaki MIYAMOTO, * Satoshi KUGINO, and Takahiro NAKAMOTO \\ Department of Chemical Science and Engineering, Ariake National College of Technology (150, Higashihagio-machi, \\ Omuta, Fukuoka 836-8585, Japan)
}

Received December 1, 1999 ; Accepted January 17, 2000

\begin{abstract}
The synthesis of manganese dioxide by spray pyrolysis has been investigated as a cathode material of lithium/manganese dioxide cell. Spraying solutions with $\mathrm{Na} / \mathrm{Mn}$ ratios of 0.0-0.7 were prepared by mixing sodium acetate and manganese acetate. Sodium manganese composite oxides were obtained by spray pyrolysing the resulting solutions at $500^{\circ} \mathrm{C}$. $\gamma-\mathrm{MnO}_{2}$ was formed by extraction of sodium ion from the composite oxides in nitric acid solution. The formation of $\alpha-\mathrm{MnO}_{2}$, phase was observed with $\mathrm{Na} / \mathrm{Mn}$ ratios of above 0.3 . The powders were in a range of $0.5-2 \mu \mathrm{m}$ and the specific surface areas were $221-254 \mathrm{~m}^{2} \mathrm{~g}^{-1}$. The discharge capacities (281-283 $\left.\mathrm{mAh} \mathrm{g}^{-1}\right)$ of the products obtained with $\mathrm{Na} / \mathrm{Mn}$ ratios of below 0.3 were higher than that of electrolytic manganese dioxide $\left(207 \mathrm{mAh} \mathrm{g}^{-1}\right)$.
\end{abstract}

Key Words : Spray Pyrolysis, Manganese Dioxide, Lithium Primary Cell

\section{1 緒 言}

微粒子で比表面皘の大きな粉末を合成するう法として、䟧 霧熟分解法がある。この力法は、金属塩を有する溶液を微綝 な液滴とし，高温に加熟した雲粗鏹に導入することにより， 慆間的に溶媒の除去及び熟分僻老起こさせ，速続的に組成が 均一で，粒度分布の狭い生成物が得られるという特徴がある。

リチゥム二次雪池の正梂活物啠である $\mathrm{LiCoO}_{2}$ または

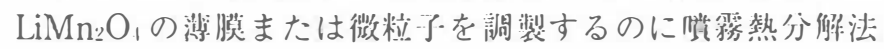
を用い，優れた電池特性:のものが得られることが郝告されて いる1-31. 一方, リチゥム一次需池肞活物質としての二酸 化マンガンの報尙例はない.

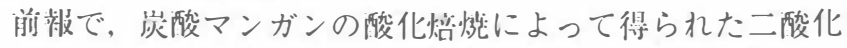
マンガンと水酸化ナトリウムの混合物を加熟し，さらに生成 物を酸溶液小に添杊することにより、留池性能に渗れた $\gamma$ 形 絬晶の二酸化マンガンが坐成することを明らかにした11。ま

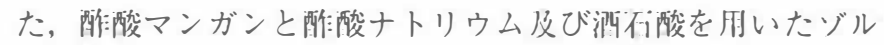

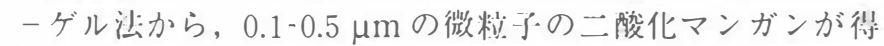
られ，リチウム一次電池用正極活物貿として優れた電池性能

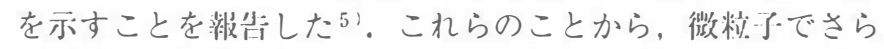
に需池特性に優れた二酸化マンガンを学霧熟分僻法で合成す ることを試みた。

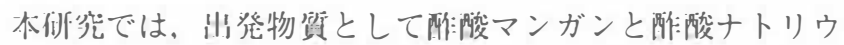
ムを用い, 両者のモル比を変えた漉合溶液を超音波法で霧化 し, 電父邩で熟分解し，さらに生成物を酸溶液中に添加する ことにより二酸化マンガンを調製した。これを正極活物質と したリチゥムー二酸化マンガン一次電池を跑作し，電池性能
を梲詩した。

\section{2 実 験}

出発物質には, 酿酸マンガン（II）四水和物（Mn$\left.\left(\mathrm{CH}_{3} \mathrm{COO}\right)_{2} \cdot 4 \mathrm{H}_{2} \mathrm{O}\right)$, 莋酸ナトリウム $\left(\mathrm{CH}_{3} \mathrm{COONa}\right)$ を用 い，酢酸マンガンに対する酢酸ナトリウムのモル比（以後 $\mathrm{Na} / \mathrm{Mn}$ 比と記す）を0.0，0.3，0.5，0.7 と変えた混会溶液 を伐用した。この溶液中の唒酸マンガンの浱度は $0.5 \mathrm{~mol} ・$ $\mathrm{dm}^{-3}$ とした。

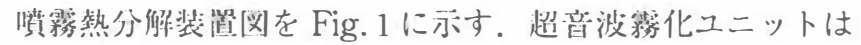
本多電子製のものを使用し, 公温で $2.4 \mathrm{MHz}$ の超音波で蓩 化した。ミストは酸素キャリヤーガス（流速 $5.3 \mathrm{~cm} \mathrm{~s}^{-1}$ )

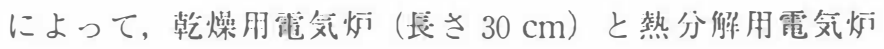

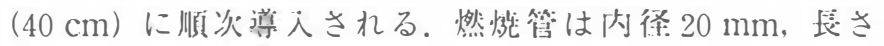
$1.0 \mathrm{~m}$ のものを使用した，乾燥用では主に液滴中の水の烝発

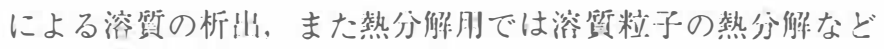
の過程を経て精了が生成し，燃婒管の出口に設管したガラス 䄉維フィルター（Advantec 㡀，GA200）で回仪される。後 述する熟分析の結果より, 乾燥用電気灯温度は $200^{\circ} \mathrm{C}$, 熟分

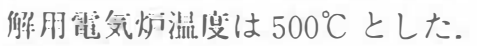

得られた熟分解物についてはゾルーゲル法の場会うと同様, 分㒛物 $1 \mathrm{~g}$ に対して $4 \mathrm{~mol} \mathrm{dm}^{-3}$ の硝酸溶液 $20 \mathrm{~cm}^{3}$ を共栓

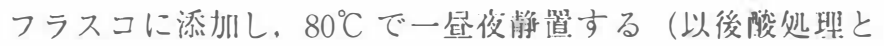
荆す)。その後ろ過, 水洗し, $150^{\circ} \mathrm{C}$ で乾燥した。さらにリ チウムー次電池の正極活物質として用いるために $375^{\circ} \mathrm{C} て ゙ 5$ 懗閶加熟した。 


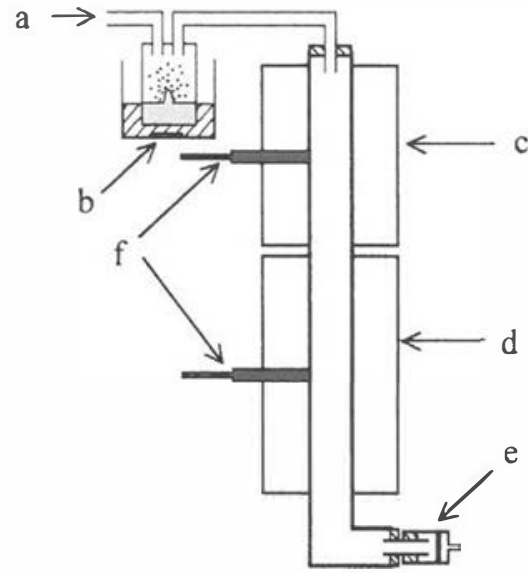

Fig. 1 Schematic diagram of the experimental apparatus. (a) $\mathrm{O}_{2}$ carrier gas, (b) Ultrasonic vibrator, (c) Electric furnace (for evacuation of water), (d) Electric furnace (for decomposition and oxidation), (e) Filter paper, (f) Thermocouple.

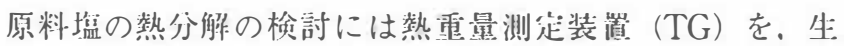
成物の同定はX 線回折装渻（XRD，30 kV，40 mA）を，粒 子の形態钼繁には走査型電子湿微鏡（SEM）を用いた。生 成物の比表而皘測症はBET 法により，生成物の二酸化マン ガン含有率は過マンガン酸滴定法で, 生成物及び溶液中のマ ンガン量の測定はキレート敵㽰法で行った。

電池の作成及び試験法も前報引と间椂，正極合剂には，活 物質： $25 \mathrm{mg}$ ，グラファイト：4 mg，アセチレンブラック： $4 \mathrm{mg}$ ，テフロン粉末：6 mg とし，これらを成型したものを 用いた，負極には金属りチウムを，電解液にはプロピレンカ ーボネート（PC）とジメトキシエタン（DME）の体積比 $1: 1$ の過熄絜酸リチウム $1 \mathrm{~mol} \mathrm{dm}^{-3}$ 溶液を朋いた。電流 密度を $0.44 \mathrm{~mA} \mathrm{~cm}^{-2}$ とし, $2.0 \mathrm{~V}$ までの放電異星を测分し た。比較のために熋解二酸化マンガン (EMD, 国際共通二

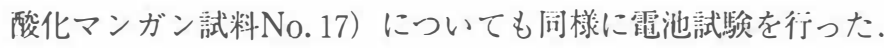

\section{1 二酸化マンガンの調製}

\section{3 結果と考察}

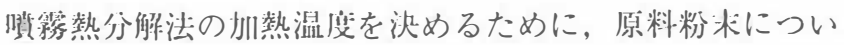
てTG 测定を行った。酢酸ナトリウムは, $400^{\circ} \mathrm{C}$ から重量減

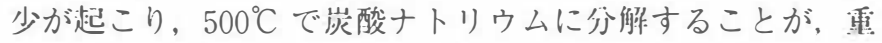
最減少率とXRD から確認された。一方, 䝫陵マンガンは, 結昆水が $150^{\circ} \mathrm{C}$ までに坊陫し, 約 $200^{\circ} \mathrm{C}$ で然水醀酸マンガン の分解が始まり， $500^{\circ} \mathrm{C}$ では $\mathrm{Mn}_{3} \mathrm{O}_{4}$ が止成することが分か った。 $\mathrm{Na} / \mathrm{Mn}$ 比 0.3 の混命物は, 酢酸マンガンに類似した

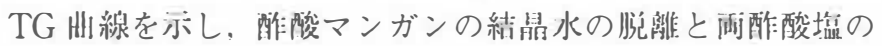
分解が起こり， $500^{\circ} \mathrm{C}$ ではナトリウムーマンガン䙡合酸化物 が生成していることが XRDからも確認された，TGの結果

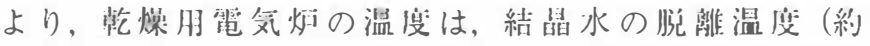

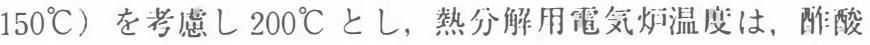
ナトリウムの分解溫度から $500^{\circ} \mathrm{C}$ とした。

Fig. 2 に笔原料である莋酸ナトリウムと陮婹マンガンの

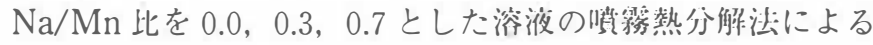
生成物の $\mathrm{X}$ 線回折四を示す。 $\mathrm{Na} / \mathrm{Mn}$ 比 0.0 (酢酸マンガン だけ）では， $\mathrm{Mn}_{2} \mathrm{O}_{\text {. }}$ と $\mathrm{Mn}_{3} \mathrm{O}_{4}$ の国折ピークが帮められる が, 0.3 では雨者のピークは消失し, $\mathrm{Na}_{1} \mathrm{Mn}_{14} \mathrm{O}_{27} \cdot 9 \mathrm{H}_{2} \mathrm{O}$ の ピークだけが現れ，さらに $\mathrm{Na} / \mathrm{Mn}$ 比の增玑とともにピーク
強度が熄大することが認められた。

水酸化ナトリウムと二酸化マンガンの混合物では ${ }^{4)} \mathrm{Na}$ Mn 比 0.75 で，酢酸ナトリウムと酢酸マンガンを明いたゾ ルーゲル法らてではNa/Mn 比 0.5 以上で, $\mathrm{Na}_{0.70} \mathrm{MnO}_{2.05}$ が生 成することを碓認した。しかし，本法では $\mathrm{Na} / \mathrm{Mn}$ 比を 0.7 に增加しても $\mathrm{Na}_{0}{ }_{70} \mathrm{MnO}_{2.05}$ の化成は涊められなかった。

䉓気炉に導入した溶液量と得られた生成物のそれぞれのマ ンガン埋を测定した結果, 混合溶液の $\mathrm{Na} / \mathrm{Mn}$ 比に関和らず マンガン量の可收率は30-40\% でほぼ一定であった。TGの 結果より，酢酸ナトリウムの分解開始温度は約 $400^{\circ} \mathrm{C}$ と附酒夋 マンガンに比べて約 $200^{\circ} \mathrm{C}$ 高い。そのため, 酢酸マンガンに 比べて醀酸ナトリウムの才が，より多く未反心のまま電気炉 を通過していると考えられる。 $\mathrm{Na} / \mathrm{Mn}$ 比 0.7 の混合溶液の 霧を笔気伢に導人しても， $\mathrm{Na} / \mathrm{Mn}$ 原子比 0.70 の酸化物であ る $\mathrm{Na}_{0.70} \mathrm{MnO}_{2.05}$ の生成は,ナトリウム量が不足となるため 困難となり，低い $\mathrm{Na} / \mathrm{Mn}$ 原子比の酸化物である $\mathrm{Na}_{4} \mathrm{Mn}_{14}$ $\mathrm{O}_{27} \cdot 9 \mathrm{H}_{2} \mathrm{O}$ だけが生成したと考えられる。

次に加熟生成物の酸処理物の X 線国折図を Fig. 3 に示す. 出発物質中の $\mathrm{Na} / \mathrm{Mn}$ 比 0.0 からのものは $\mathrm{EMD}$ と同じパ夕 ーンを示し， $\gamma$ 形二酸化マンガンの結昆を有していると考え られる. $\mathrm{Na} / \mathrm{Mn}$ 比 0.3 では，新たに $\alpha$ 形二酸化マンガンの ピーク6)が㴓められ， 0.5 以上ではピーク強度が高くなるこ とが分かった．本法の場合はゾルーゲル法らにに比べ, $\mathrm{Na}$ $\mathrm{Mn}$ 比 0.7 でも $\alpha$ 非二酸化マンガンのピーク弶度は嫋く, $\gamma$ 形二酸化マンガンのピークも明確に惩められた。

二酸化マンガン含有率の測定を行った絬果. $\mathrm{Na} / \mathrm{Mn}$ 比 0.0-0.3 での酸処理物の二酸化マンガン含有涪が 91-93\% であ

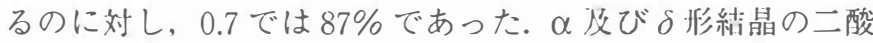
化マンガンは, $\gamma$ 形結䦠のものに比べて結合水と $\mathrm{Mn}^{3+}$ イ才 ンを多く含むため二酸化マンガン含有率が低いと報告されて いる7)。前記したXRDの結果より， $\mathrm{Na} / \mathrm{Mn}$ 比の增加と共 に $\alpha$ 形二酸化マンガンが多く生成するため二酸化マンガン 含有梁が低下したと考えられる。

この酸処理では加熟生成物に含まれる $\mathrm{Mn}^{2+}$ 及び $\mathrm{Mn}^{3+}$ イ オンが酸浴液に単に浴出するだけでなく，阔相队の $\mathrm{Mn}^{3+}$ イ オンが（1）式で示す不均化反応を起こし, 新たな二酸化マ

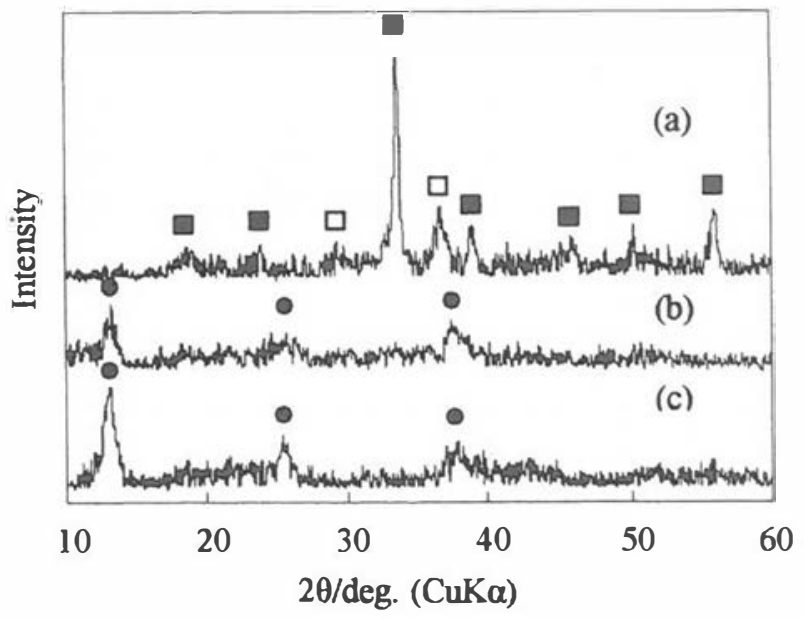

Fig. 2 X-ray diffraction patterns of the heated products for different $\mathrm{Na} / \mathrm{Mn}$ ratios* in starting materials.

(a) $\mathrm{Na} / \mathrm{Mn}=0.0$, (b) $\mathrm{Na} / \mathrm{Mn}=0.3$, (c) $\mathrm{Na} / \mathrm{Mn}=0.7$

: $\mathrm{Na}_{4} \mathrm{Mn}_{14} \mathrm{O}_{27} \cdot 9 \mathrm{H}_{2} \mathrm{O}, \square: \mathrm{Mn}_{2} \mathrm{O}_{3}, \square: \mathrm{Mn}_{3} \mathrm{O}_{4}$

* The molar ratio of sodium acetate to manganese acetate. 
ンガンが坐成すると考えられる。このことはFig.4で亦す SEM 写真で，粒子表们に新たな絬晶の析出が観察されるこ とからも推测される。 また二酸化マンガン含有率の絬果から， ナトリウムーマンガン酸化物を含むものは, この不均化父忍 が起こりにくくなると考えられる。

$$
2 \mathrm{Mn}^{3+} \longrightarrow \mathrm{Mn}^{2+}+\mathrm{Mn}^{4+}
$$

\section{2 二酸化マンガンの特性}

Fig. 4 に出発物斦中の $\mathrm{Na} / \mathrm{Mn}$ 比 0.3 の㺫熹生成物とその 婹処理物の SEM 等㝵を示す. $\mathrm{Na} / \mathrm{Mn}$ 比による粒子版状の 違いは明碓には認められず，加熹生成物の粒子は 0.5-2 $\mu \mathrm{m}$ のほほ球䏒をしている。酸処理後は（1）式の不均化反心で 生成した二酸化マンガンと考えられる針状絬昆が粒子表酎を

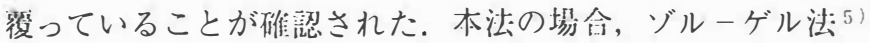
よりも粒子径は数倍大きいが，訟処理物の表陑を㠅う針状絬 晶がより多く㴓められる。

酸処理物の比表们皘を测定した絬果, $\mathrm{Na} / \mathrm{Mn}$ 比 0.0 で $254 \mathrm{~m}^{2} \mathrm{~g}^{-1}$ と EMD $\left(37 \mathrm{~m}^{2} \mathrm{~g}^{-1}\right)$ に比べて約 7 倍高い佰を 亦し，この比の增加と些に比表面榓は減少するが， 0.7 でも

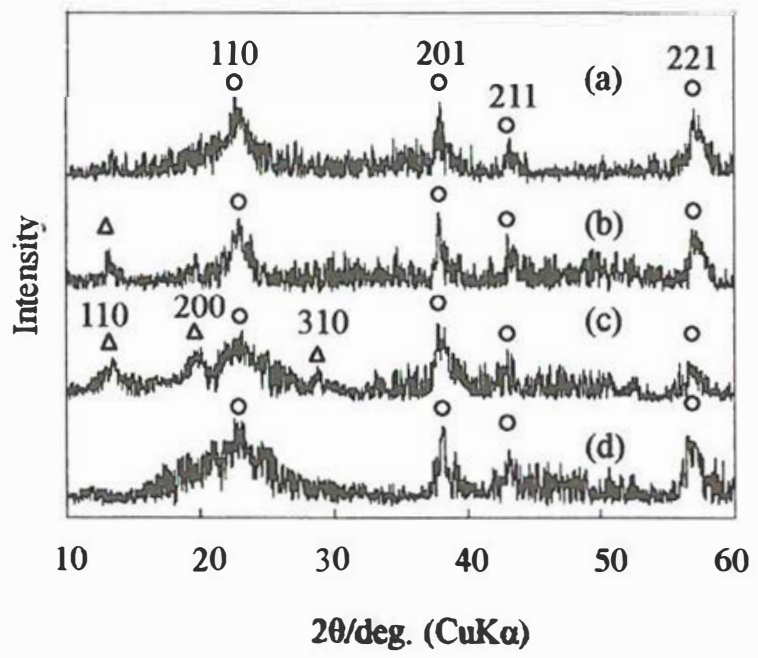

Fig. 3 X-ray diffraction patterns of the products by acid treatment (4 mol dm${ }^{-3} \mathrm{HNO}_{3}$ soln.).

(a) $\mathrm{Na} / \mathrm{Mn}=0.0$, (b) $\mathrm{Na} / \mathrm{Mn}=0.3$, (c) $\mathrm{Na} / \mathrm{Mn}=0.7$, (d) EMD. $\mathrm{O}: \gamma-\mathrm{MnO}_{2}, \triangle: \alpha-\mathrm{MnO}_{2}$

Numbers over the peaks are hkl values.
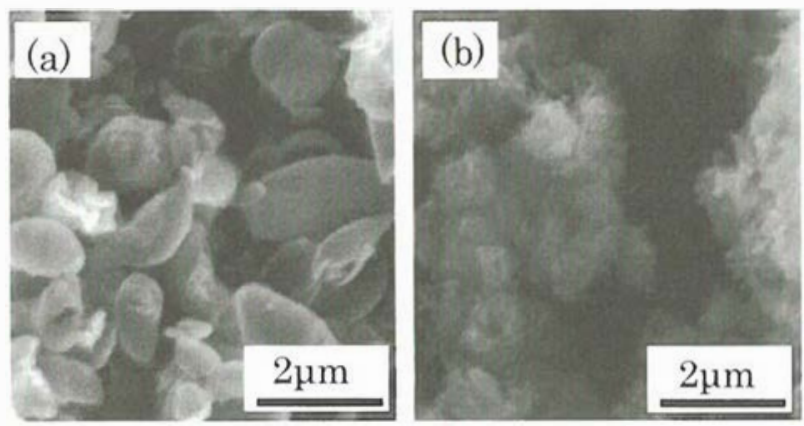

Fig. 4 Scanning electron micrographs for (a) the heated product with $\mathrm{Na} / \mathrm{Mn}$ ratio of 0.3 and (b) the product prepared by acid treatment of (a).
$221 \mathrm{~m}^{2} \mathrm{~g}^{-1}$ と槀い值である. $\mathrm{Na} / \mathrm{Mn}$ 比 0.0-0.3での比表咞 秘は，ゾルーゲル法で得られるものよりも約 $5 \%$ 高い。本

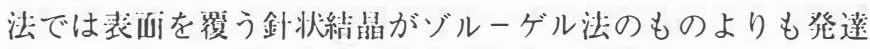
しているため，高い比表皿積を示したと考えられる。

\section{3 電池特性}

酸処理物の放電州線を Fig. 5 に示す. $\mathrm{Na} / \mathrm{Mn}$ 比 0.0 と 0.3 のものについて, 2.85-2.75 V で平坦な電压を示し, $2.0 \mathrm{~V}$ ま での放電谷量は, EMD (207 $\left.\mathrm{mAh}^{-1}\right)$ を拥いたものに比 べて約 35\% 以上需い值（281-283 $\left.\mathrm{mAh}^{-1}\right)$ を示した。こ の佃は、ゾルーゲル法によるものよりも約 $10 \%$ 高い. Na/ $\mathrm{Mn}$ 比 0.5 以上では比の增加とともに放電谷量は減少する

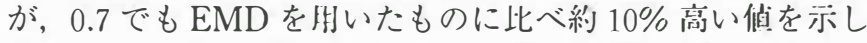
た. $\mathrm{Na} / \mathrm{Mn}$ 比が增㺫するにつれ，放電初剘の電理が高くな り，放笪州線は平埧部のない S 字カーブを描くことが琹め られた。これは絬鼠形の影䬸によるものと考えられる。 Thackeray $^{6) の ~} \gamma$ 形及び $\alpha$ 形二酸化マンガンを朋いたリチ ウム電池においても间様な倾问を示している。

$\mathrm{Na} / \mathrm{Mn}$ 比 0.0-0.3 での生成物が高い放電"谷量を示した理且

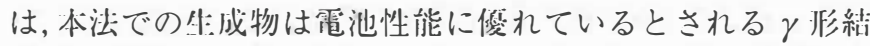
晶の二酸化マンガン4.6)であり,さらにゾルーゲル法らによ

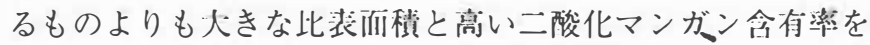

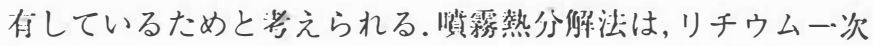

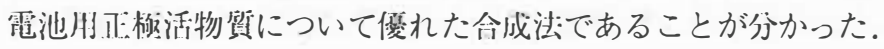

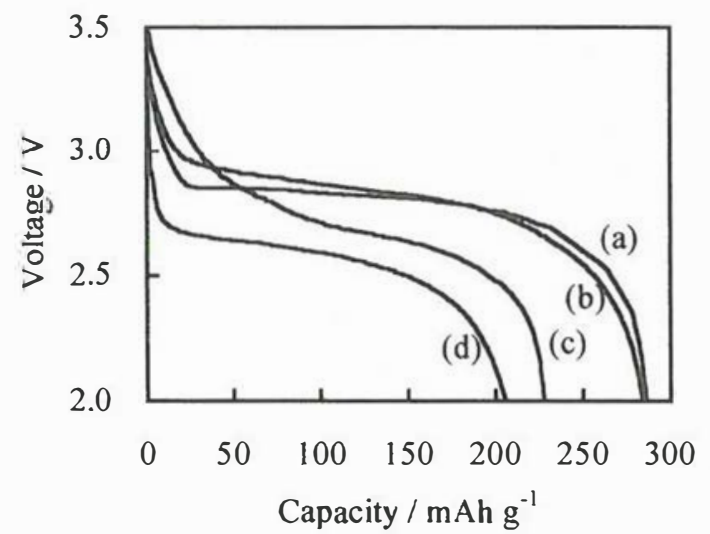

Fig. 5 Discharge curves $\left(0.44 \mathrm{~mA} \mathrm{~cm}^{-2}\right)$ for the products prepare at different ratios of $\mathrm{Na} / \mathrm{Mn}$ in starting materials. Electrolyte : $1 \mathrm{~mol} \mathrm{dm}^{-3} \mathrm{LiClO}_{4} / \mathrm{PC}+\mathrm{DME}$ (1/1 by volume). (a) $\mathrm{Na} / \mathrm{Mn}=0.0$, (b) $\mathrm{Na} / \mathrm{Mn}=0.3$, (c) $\mathrm{Na} / \mathrm{Mn}=0.7$, (d) $\mathrm{EMD}$.

\section{文 献}

1) P. Fragnaud and D. M. Schleich, Sens. Actuators A., 51, 21 (1995)

2) P. Fragnaud, T. Brousse, and D. M. Schleich, J. Power Sources, 63, 187 (1996).

3) D. G. Fauteux, A. Massucco, J. Shi, and C. LampeÖnnerud, J. Appl. Electrochem., 27, 543 (1997).

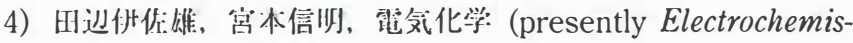
try), 57, 164 (1989).

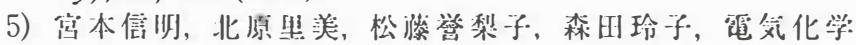
(presently Electrochemistry), 68, 95(2000).

6) M. M. Thackeray, Prog. Solid State Chem., 25, 1 (1997).

7) H. Abbas and S. A. Nasser, J. Power Sources, 55, 15 (1996). 